УДК 327

DOI $10.21564 / 2075-7190.41 .168239$

Trebin Mikhail Petrovich, Doctor of Philosophical Sciences, Professor, Head of the Department of Sociology and Political Science, Yaroslav Mudryi National Law University, Kharkiv, Ukraine e-mail:m.p.trebin@nlu.edu.ua ORCID ID: 0000-0002-1328-9865

\title{
THE PHENOMENON OF TERRORISM: UNDERSTANDING THE ESSENCE
}

The essence of the phenomenon of terrorism and its main features is revealed. Above all, violence is a significant sign of terrorism. There are three types of theories explaining the sources of violence: the first type unites those concepts that derive violence from human nature; the second - derives the use of violence from the economic and social conditions of society; the third - connects violence with the dynamics of conflict. When carrying out terrorist actions, one should take into account the obvious and latent elements of violence. The obvious element of violence is connected with the implementation of direct terrorist acts, the latent element of violence is connected with the fact that the terrorist act launches the mechanism of compelling people to do as way demanded by terrorists. The author's Definition of terrorism is proposed.

Keywords: terrorism, terrorist act, violence, war, definition of terrorism.

Problem setting. The modern world after the events of September 11, 2001 lives with the understanding that along with the global problems that were already perceived by mankind at the end of the twentieth century (the threat of nuclear war, environmental pollution, climate change, poverty in some regions of the planet), there was another one threat, which can also be attributed to global - terrorism. Today, neither a resident of Paris, nor London, nor Tokyo, nor Istanbul, nor any other city on the planet can feel completely safe. Terrorists live, study and work alongside ordinary citizens, go to church, mosques or synagogues, do not stand out from the crowd, but with time they will become cruel murderers, sowing around death and horror. Terrorism is multifaceted and diverse; it is transformed with humanity; it mimics the fight against injustice, inequality, oppression, the national liberation struggle and other social and political processes that can be perceived as ambivalent. Therefore, insight into the essence of terrorism, understanding the causes, methods of its struggle is particularly relevant for Ukraine, which for the fifth year has become the target of a "hybrid" war, during which the enemy actively uses terrorist acts. 
Recent research and publications analysis. The phenomenon of terrorism was particularly actively studied by scientists after the tragedy in America, although even before that it was in their field of vision. But only in the last two decades hundreds of books and thousands of articles on this topic have been written, dozens of encyclopedias have been published, investigating this phenomenon. Among scientists studying the nature, forms and methods of combating terrorism, we can distinguish such scientists in other countries as Max Abrahms, Anna Marie Brennan, Martha Crenshaw, Laura Dugan, Joshua D. Freilich, Antonio Giustozzi, Stefan Goertz, Mark S. Hamm, Ahmed S. Hashim, Bruce Hoffman, Brian Michael Jenkins, Seth G. Jones, Paul Kamolnick, S. Paul Kapur, Tuncay Kardaş, Gary LaFree, Walter Laqueur, Susanne Martin, Michele R. McPhee, Erin Miller, Travis Morris, Diego Muro, Petter Nesser, Fernando Reinares, Alex P. Schmid, Ali H. Soufan, Ramon Spaaij, Anne Stenersen, Emerson Vermaat, Leonard Weinberg, Paul Wilkinson, Murat Yeşiltaş and others [1-38]. Much attention was paid to the study of terrorism by Ukrainian scholars such as Volodymyr Antypenko, Alexander Bardin, Victoria Belyanska, Andriy Demenko, Mykola Horlach, Victor Hryshchuk, Volodymyr Kantsir, Vasily Krutov, Boris Leonov, Volodymyr Lipkan, Vladimir Mandragelya, Anatoly Movchan, Ivan Musiienko, Volodymyr Smolianiuk, Vyacheslav Yemelianov and others [39-46].

Paper objective. The author remembers the statement perfectly W. Laqueur: "It can be predicted with confidence that disputes about a comprehensive, detailed definition of terrorism will continue for a long time, that they will not result in consensus and that they will make no noticeable contribution to the understanding of terrorism" [25, p. 135]. But at the same time, author believes that any phenomenon or process should be comprehensively considered, knowledge of the essence is a necessary scientific procedure, therefore the purpose of the article is to penetrate into the essence of the phenomenon of terrorism.

Paper main body. There are arguably numerous definitions of "terrorism". By some accounts, there could be in excess of one hundred distinct definitions [47, p. 1]. In addition, because of its contentious nature, some would argue that: "There is no agreement on the definition [of terrorism $-M$. T.], no systematic analysis of fragmented data, no applicable game models ....in fact, we cannot even say with any certainty whether the phenomenon is on the rise" [48, p. 29]. Understanding terrorism as a global problem of the present and finding out the solution against it is an important epistemological task that requires an immediate settlement. "Terrorism is a systemic phenomenon, in which ideological, political, moral-value, psychological, ethno-cultural and other subsystems are united", - note B. Sidorov and V. Kirshin [49, p. 105]. In addition, the genesis of this phenomenon shows its significant transformation: the forms of committing terrorist acts are changing, there is a shift in the sphere of the target impact of terrorists, changes in their methods 
of operation, features of organizational construction, etc. Terrorism also has much in common with other forms of social protest and violence - by aggression, armed struggle, military conflicts of varying degrees of intensity, guerrilla actions, sabotage, etc. [50]. Table 1 presents the main characteristics of terrorism, guerrilla and conventional war as modes of violent struggle [51].

Table 1.

Characteristics of Terrorism, Guerrilla and Conventional War as Modes of Violent Struggle

\begin{tabular}{|c|c|c|c|}
\hline & $\begin{array}{c}\text { Conventional } \\
\text { war }\end{array}$ & Guerrilla & Terrorism \\
\hline $\begin{array}{l}\text { Unit size in } \\
\text { battle }\end{array}$ & $\begin{array}{l}\text { Large (armies, corps, } \\
\text { divisions) }\end{array}$ & $\begin{array}{l}\text { Medium (platoons, } \\
\text { companies, battalions) }\end{array}$ & $\begin{array}{l}\text { Small (usually less } \\
\text { than ten persons) }\end{array}$ \\
\hline Weapons & \begin{tabular}{|l} 
Full range of \\
military hardware \\
(air force, armor, \\
artillery, etc.)
\end{tabular} & $\begin{array}{l}\text { Mostly infantry-type } \\
\text { light weapons but } \\
\text { sometimes artillery } \\
\text { pieces as well }\end{array}$ & $\begin{array}{l}\text { Hand guns, hand } \\
\text { grenades, assault } \\
\text { rifles and } \\
\text { specialised weapons, } \\
\text { e.g., car bombs, } \\
\text { remote-control } \\
\text { bombs, barometric } \\
\text { pressure bombs }\end{array}$ \\
\hline Tactics & $\begin{array}{l}\text { Usually joint } \\
\text { operations involving } \\
\text { several military } \\
\text { branches }\end{array}$ & $\begin{array}{l}\text { Commando-type } \\
\text { tactics }\end{array}$ & $\begin{array}{l}\text { Specialised tactics: } \\
\text { kidnapping, } \\
\text { assassinations, } \\
\text { carbombing, } \\
\text { hijacking, } \\
\text { barricade-hostage, } \\
\text { etc. }\end{array}$ \\
\hline Targets & $\begin{array}{l}\text { Mostly military } \\
\text { units, industrial } \\
\text { and transportation } \\
\text { infrastructure }\end{array}$ & $\begin{array}{l}\text { Mostly military, } \\
\text { police and } \\
\text { administration staff, } \\
\text { as well as political } \\
\text { opponents }\end{array}$ & $\begin{array}{l}\text { State symbols, } \\
\text { political opponents, } \\
\text { and the public } \\
\text { at large }\end{array}$ \\
\hline $\begin{array}{c}\text { Intended } \\
\text { impact }\end{array}$ & Physical destruction & $\begin{array}{l}\text { Mainly physical } \\
\text { attrition of the enemy }\end{array}$ & Psychological coercion \\
\hline $\begin{array}{l}\text { Control of } \\
\text { territory }\end{array}$ & Yes & Yes & No \\
\hline
\end{tabular}




\begin{tabular}{|c|l|c|l|}
\hline Uniform & \multicolumn{1}{|c|}{ Wear uniform } & Often wear uniform & Do not wear uniform \\
\hline $\begin{array}{c}\text { Recognition } \\
\text { of war zones }\end{array}$ & $\begin{array}{l}\text { War limited } \\
\text { to recognised } \\
\text { geographical }\end{array}$ & $\begin{array}{c}\text { War limited to the } \\
\text { country in strife }\end{array}$ & $\begin{array}{l}\text { No recognised war } \\
\text { zones. Operations } \\
\text { carried out zones } \\
\text { world-wide }\end{array}$ \\
\hline $\begin{array}{c}\text { International } \\
\text { legality }\end{array}$ & $\begin{array}{l}\text { Yes, if conducted } \\
\text { by rules }\end{array}$ & $\begin{array}{l}\text { Yes, if conducted } \\
\text { by rules }\end{array}$ & No \\
\hline $\begin{array}{c}\text { Domestic } \\
\text { legality }\end{array}$ & Yes & \multicolumn{1}{|c|}{ No } & No \\
\hline
\end{tabular}

Unfortunately, at the UN level, no agreement has yet been reached on the unequivocal definition of terrorism [52, p. 120-132]. American researchers of terrorism emphasize that this phenomenon is easier to describe than to give it a clear, unambiguous interpretation. This is how American researcher Brian Jenkins approaches the interpretation of this concept. Terrorism, he stresses, "is defined by the nature of the act, not by the identity of the perpetrators or the nature of their cause. All terrorist acts are crimes - murder, kidnapping, arson. Many would also be violations of the rules of war, if a state of war existed. All involve violence or the threat of violence, often coupled with specific demands. The violence is directed mainly against civilian targets. The motives are political. The actions generally are carried out in a way that will achieve maximum publicity. The perpetrators are usually members of an organized group, and unlike other criminals, they often claim credit for the act. And finally the act is intended to produce effects beyond the immediate physical damage" [53, p. 2-3]. Richard A. Falkenrath in his definition of terrorism also emphasizes the religious aspect. Terrorism for him - "is typically defined as premeditated violence used to achieve specific political, social, or religious objectives by instilling fear among the general public" [54, p. 149]. $\mathrm{V}$. Yemelyanov in his monograph "Terrorism - as a phenomenon and as a crime" gives a definition of terrorism, which emphasizes the political and legal aspect of the phenomenon: "Terrorism is a publicly-made, generally dangerous act or threat, aimed at intimidating a population or social groups, with a view to directly or indirectly influencing or rejecting any decision in the interests of terrorists" [55, p. 28]. According to experts, among the definitions of terrorism, the following looks interesting: "Terrorism is the use of non-state violence or threats of violence in order to cause panic in society, to weaken and even to overthrow the government and cause political changes; it is aimed at destabilizing state regimes, disturbing people's concerns through their defenselessness against the threat of violence, the change as a result of this state power in the country, on the exercise of other political, religious or ethnic aspirations" [56, p. 7]. Although this definition of terrorism is not perfect. 
However, the definition of terrorism itself is very important [57, p. 345]. Identifying any action as a terrorist means not just claiming that it has certain characteristics but also condemning it. Let's try to clarify a number of points related to the definition of terrorism. Each definition must contain the essential features of the phenomenon. In our view, when it comes to terrorism, then, firstly, it refers to violence. It is well presented Alex P. Schmid in Table 2 [58, p. 58-59].

Table 2.

The Spectrum of Political Action

\begin{tabular}{|c|c|}
\hline \multicolumn{2}{|c|}{ State of Peace } \\
\hline State actor & Non-state actor \\
\hline \multicolumn{2}{|c|}{ Conventional Politics } \\
\hline $\begin{array}{l}\text { I. Rule of Law (routinized rule, legitimated } \\
\text { by tradition, customs, } \\
\text { constitutional procedures) }\end{array}$ & $\begin{array}{l}\text { I. Opposition politics (lobbying among } \\
\text { power holders, formation of } \\
\text { opposition press and parties, } \\
\text { rallies, electoral contest, litigation } \\
\text { [use of courts for political struggle]) }\end{array}$ \\
\hline \multicolumn{2}{|c|}{ Unconventional Politics } \\
\hline $\begin{array}{l}\text { II. Oppression (manipulation of } \\
\text { competitive electoral process, } \\
\text { censorship, surveillance, harassment, } \\
\text { discrimination, infiltration of } \\
\text { opposition, misuse of emergency } \\
\text { legislation) }\end{array}$ & $\begin{array}{l}\text { II. Non-violent action (social protest for } \\
\text { political persuasion of rulers and } \\
\text { masses; demonstrations to show } \\
\text { strength of public support; } \\
\text { non-cooperation, civil } \\
\text { disobedience, and other forms of } \\
\text { non-violent action) }\end{array}$ \\
\hline \multicolumn{2}{|c|}{ Violent Politics } \\
\hline $\begin{array}{l}\text { III. Violent repression for control of state } \\
\text { power }\end{array}$ & $\begin{array}{l}\text { III. Use of violence for contestation } \\
\text { challenging state power }\end{array}$ \\
\hline $\begin{array}{l}\text { III.1. (political justice. political } \\
\text { imprisonment) }\end{array}$ & III. 1. Material destruction \\
\hline III. 2. Assassination & $\begin{array}{l}\text { III. 2. Assassination. (individuated } \\
\text { political murder) }\end{array}$ \\
\hline $\begin{array}{l}\text { III. 3. State-terrorism (torture, death } \\
\text { squads, disappearances, concentration } \\
\text { camps) }\end{array}$ & $\begin{array}{l}\text { III. 3. Terrorism (de-individuated political } \\
\text { murder) }\end{array}$ \\
\hline III. 4. Massacres & III. 4. Massacres \\
\hline III. 5. Internal war & III. 5. Guerrilla warfare \\
\hline III. 6. Ethnocide/politicide/genocide & $\begin{array}{l}\text { III. 6. Insurgency, Revolution (if } \\
\text { successful) }\end{array}$ \\
\hline
\end{tabular}


There were three types of theories explaining the sources of violence [59]. The first type combines the concepts that draw violence from the nature of man. The whole history of human civilization is connected with violence. "The very first law of nature, - wrote V. Soloviev, - is the struggle for existence. All nature lives in the constant hostility of creatures and forces, in their wicked perturbations and the charms of someone else's life. Every creature in our world, from the smallest particles of dust to humans, speaks about one thing all of its natural life: I exist, and everything else here is only for me. Facing another one, he says to him: if I exist, then you can no longer exist, you have no place next to me. And everyone ..want all to destroy and exterminated by all. The confrontation between each and every one inevitably ends with the death of everyone - a hostile environment, finally tearing its existence and pushing it out of life, the struggle ends in death and decay..." [60, p. 71-72]. With this approach, it is assumed that there are innate tendencies, instincts (death instinct, sexual instinct), pushing people to violence. To this type can be attributed, and philosophical concepts that explain the violence inherent in man by the will to power, domination. So, Finnish researcher Tatu Vanhanen emphasizes that people must fight for power, because this is the ultimate way to distribute control over resources [61, p. 17], and therefore to a better life.

The second type of theory explains the use of violence by the economic and social conditions of society. Even Aristotle noted that the basis of violence is the inability of the authorities to establish equality in society [62, p. 420-422, 577]. Economic and social inequality causes the differentiation of society into groups, social classes and, accordingly, contradictions and struggle between them. K. Marx, F. Engels and their followers substantiated the class antagonisms that exist in society, social inequality and exploitation. The overcoming of these antagonisms is through the establishment of social equality or, in any case, the alleviation of inequality. Accordingly, the permissible limits of differences in living standards of different classes are determined to ensure the stability of public life. Many contemporary social scientists also tend to conclude that there is a link between violence and inequality. So, Ralph Dahrendorf writes that inequality and power continue to be powerful factors in the clash of interests and struggle [63, p. 47]. Y. Antonyan stressed that today's terrorism "is not only the collision of religions, nations, civilizations, but also antagonism between the poverty of often potentially wealthy regions and the wealth of developed countries. But here, not only the very poverty itself, but also the driving force, advocates a sense of its greatest social injustice" [64, p. 337]. Professor Pak Hun concluded that inequality in income is the most important reason for political violence on materials from 62 countries of the world $[65$, p. 8$]$.

The third type of theories relates violence to the dynamics of conflict. In any society there are competing groups - economic, political, and spiritual. The initial 
state of competing groups and individuals is a potential conflict. It becomes real when the competitive state is personified when each individual begins to confront each other. This is precisely the stage when violence becomes very likely. The conflict finds its solution in the victory of one of the conflicting parties. A new hierarchy is being approved. There is a period of adaptation to the situation. This is the period when new competing groups are formed. Conflict resolution history repeats over and over again. According to P. Shikhirev, the history of the development of social conflicts and the forms of violence used in them can be divided into three main stages [66, p. 28-29]. The first involves the use of direct physical abuse. Primitive man sought to destroy another person or group if they prevented him from living. During the period of slavery, a man realized that it was better not to kill the enemy, but to make him work for himself. The second stage is political. Its content is the dominance of some social groups over others. At this stage, the principle of "agree, or I"ll kill you" dominates. The third, economic stage is based on a wide mutually beneficial social exchange. The basic principle of interaction at this stage is "give me this, and I will give you that". In parallel with these three methods of solving social conflicts (physical, political, economic) ideological and moral principles of interaction of people based on ethnic, value and legal norms were formed.

Conventional violence has two main interpretations: coercion and the use of physical force [67, p. 11-30]. In some philosophical works, violence is interpreted as limiting a person's physical and spiritual abilities, suppressing his free will. In the Italian Philosophical Encyclopedia, violence is defined as an act committed from outside against spontaneous attraction and natural movement. A. Getman, M. Panov, V. Tatsiy emphasize that violence is any restriction of fundamental human rights. The understanding of violence as an obligatory restriction of human freedom is also characteristic of some Russian researchers. Thus, Abdusalam Guseynov defines violence as "the usurpation of free will" [68, p. 9]. The most common approach to violence distinguishes those authors for whom it is synonymous with everything that harms a person.

System analysis allows us to find out the functions of violence, which are largely due to the degree of awareness of their actions by actors of violence and the ultimate goal of violence. There are so-called irrational and rational violence. The first is the process of mental disorientation (aggression), with the object subjected to substitution and violence is an end in itself (the catharsis function of violence). "Rational" violence, on the contrary, has a pronounced social or political function and is one of many means. It is worthwhile to distinguish between instrumental and symbolic (or "communicative") violence. Instrumental violence pursues a specific goal, often used as a means of forming power or redistributing it (for example, the terrorist nature of the early phase of Italian fascism and a number of movements in 
developing countries). Therefore, violence performs an instrumental function, if used for the purpose of existential destruction in the name of creating a religious, ethnic, racial or social homogeneity of society. Symbolic violence, on the contrary, is aimed not at the realization of the goal, but at the addition of the consciousness created by the propaganda of a certain image. For a society undergoing systemic transformation, it is important to remember that the phenomenon of violence in its current form has a completely new, unusual character unlike all past eras, because it is a product of a society of a qualitatively different nature, namely, a society defined as post-industrial. For such a society, the special terrorist activities of its individuals and groups were particularly characteristic.

In terms of identifying the features of violence in the commission of terrorist acts, two points must be emphasized: explicit and latent elements of violence. An explicit element of violence is connected with the implementation of direct terrorist acts, which can cause people to die, houses getting destroyed, planes, trains, etc. explode. In today's conditions, the nature of the objects of terrorist attacks and the forms of these attacks are sharply spreading. But the main threat from terrorists remains a threat to the lives and safety of people. It should be noted that the distinctive feature of modern terrorism is that it has a distinction between the immediate victim of violence and the group being the object of influence and the purpose of violence, and the degree of cruelty from this does not diminish, and perhaps even more. According to Hans Schneider, "terrorism is a process of transforming people into non-people... Terrorists are insensitive to the suffering of their victims, distanced themselves from them and predefined their criminal behavior, which causes harm to the victims. For them, the victims of terrorism are at best bargain objects, tools for achieving the goal" [69, p. 443]. Most forms of armed violence characteristic of terrorism are not its monopoly, same as their use is not evidence of what is just about terrorist practice. Here the main thing is, with what purpose these violent actions are carried out. Motives and orientation are very important in the analysis of terrorist acts. Hence, one more distinguishing feature of terrorism, which is that it combines a high level of political motivation with low participation of the masses.

The latent element of violence is related to the fact that a terrorist act launches a mechanism for coercion of people to do as terrorists demand it, to influence state structures in order to put into practice those demands that were forwarding by them, creating an atmosphere of fear and hopelessness in society. Thomas Hobbes wrote about such consequences of violence: "The worst thing is that there is an eternal fear and constant danger of violent death, and human life is lonely, poor, hopeless, stupid and short-lived" [70, p. 96]. The execution of the attack does not cover the content of terrorist acts, and they do not end at the end of the combat operation. Their main goal is not just the commission of mass killings, the elimination of 
individuals, material damage, etc., but the achievement of social resonance, intimidation of peoples and governments. Terrorism is not only a form of political violence, but also a form of political communication. Although intimidation in the past, characteristic of invasions, has often been in the shadow, since terrorism has become organized, ideologically sound and systematic, this function is even more pronounced. Preventive intimidation by terrorist acts applies to everyone: workers, bankers, employees, officials in ministries. Everyone, absolutely everyone should feel their insecurity in the face of constant evil, the variability of modern life. With the help of terrorist acts in a society, hysteria of fear, hopelessness, distrust of certain social groups, and sometimes entire nations, is manifested, which manifests itself in the growth of aggressiveness in society. Consequently, violent acts acquire the character of terrorist, if they are aimed at creating an atmosphere of fear and hopelessness. In this case, the system of terrorist means includes not only actions that directly threaten the lives and safety of people, but also bloodless preventive operations that intimidate people - arson or explosions in abandoned premises shops, offices, headquarters of political parties, industrial enterprises, etc.

Atmosphere of fear often causes an increase of aggression in society, awakens an evil, destructive element in man. Aggressiveness is inherent in man since ancient times. The "evil inclination" as well as the "good inclination" is an integral part of the human world. Terrorism is one of those triggers that reproduce the growth of aggression and violence in society, the growth of dissipative processes.

The emphasis on the explicit and latent components of terrorist activity allows to capture the fact that the explicit component of terrorist acts largely shows the instrumental function of a terrorist act as a phenomenon specific to violence; the latent component shows the genesis and dynamics of such a phenomenon as an increase in fear, a lack of output in society, and the growth of entropy processes in it.

Analysis of the main characteristics of terrorism allows us to formulate our vision of terrorism. Terrorism is a social phenomenon that is based on the use or threat of violence in the form of a terrorist act in order to create an atmosphere of fear and hopelessness in society in order to achieve the goals of terrorist actors.

Conclusions of the research. Consequently, terrorism is multifaceted, does not stop at what has been achieved and is constantly evolving, since the social phenomenon is very complex, its origin and development depend on many factors, among which, in our opinion, the most important are cultural, geopolitical, socioeconomic, religious and psychological [41, p. 44-101]. Of course, they do not exhaust the whole variety of factors influencing the emergence and development of this social phenomenon, but they create the outlines of a sociocultural matrix that reflects the most important features of terrorism. Thus, we can argue that terrorism as a social phenomenon is a multicausal, because of its destructive power, it represents a serious threat to society and the individual. 


\section{REFERENCES}

1. Abrahms, M., Beauchamp, N., Mroszczyk, J. (2017). What Terrorist Leaders Want: A Content Analysis of Terrorist Propaganda Videos. Studies in Conflict \& Terrorism, $40(11), 899-916$.

2. Abrahms, M., Conrad, J. (2017). The Strategic Logic of Credit Claiming: A New Theory for Anonymous Terrorist Attacks. Security Studies, 26(2), 279-304.

3. Abrahms, M., Mierau, J. (2017). Leadership Matters: The Effects of Targeted Killings on Militant Group Tactics. Terrorism and Political Violence, 29(5), 830-851.

4. Abrahms, M., Ward, M., Kennedy, R. (2018). Explaining Civilian Attacks: Terrorist Networks, Principal-Agent Problems and Target Selection. Perspectives on Terrorism, 12(1), 23-45.

5. Ahmed, R. (2018). Terrorist Ideologies and Target Selection. Journal of Applied Security Research, 13(3), 376-390.

6. Akcinaroglu, S., Tokdemir, E. (2018). To Instill Fear or Love: Terrorist Groups and the Strategy of Building Reputation. Conflict Management and Peace Science, 35(4), 355-377.

7. Alakoc, B. P. (2017). Competing to Kill: Terrorist Organizations versus Lone Wolf Terrorists. Terrorism and Political Violence, 29(3), 509-532.

8. Alonso, R. (2016). Terrorist Skin, Peace-Party Mask: The Political Communication Strategy of Sinn Fein and the PIRA. Terrorism and Political Violence, 28(3), 520-540.

9. Angstrom, J. (2017). Escalation, Emulation, and the Failure of Hybrid Warfare in Afghanistan. Studies in Conflict \& Terrorism, 40(10), 838-856.

10. Brennan, A. M. (2018). Transnational Terrorist Groups and International Criminal Law. Abingdon: Routledge.

11. Crenshaw, M., LaFree, G. (2017). Countering Terrorism. Washington, DC: Brookings Institution Press.

12. Giustozzi, A. (2018). The Islamic State in Khorasan: Afghanistan, Pakistan and the New Central Asian Jihad. London: Hurst.

13. Goertz, S. (2017). Islamistischer Terrorismus: Analyse - Definitionen - Taktik. Heidelberg: C. F. Muller.

14. Goertz, S. (2018). Der neue Terrorismus: Neue Akteure, neue Strategien, neue Taktiken und neue Mittel. Wiesbaden: Springer VS

15. Hamm, M. S., Spaaij, R. (2017). The Age of Lone Wolf Terrorism. New York: Columbia University Press

16. Hashim, A. S. (2018). The Caliphate at War: The Ideological, Organisational and Military Innovations of Islamic State. London: Hurst.

17. Haywood, T. J. (2017). Determinants of Terrorist Target Selection: A Quantitative Analysis. Master's Thesis, University of Central Florida, Orlando, United States. Retrieved from http://purl.fcla.edu/fcla/etd/CFE0006744.

18. Hoffman, B., Reinares, F. (Eds.) (2014). The Evolution of the Global Terrorist Threat: From 9/11 to Osama bin Laden's Death. New York: Columbia University Press.

19. Jenkins, B. M. (2017). The Origins of America's Jihadists. Santa Monica: RAND Corporation. 
20. Jones, S. G. (2017). Waging Insurgent Warfare: Lessons from the Vietcong to the Islamic State. New York: Oxford University Press.

21. Kamolnick, P. (2017). The Al-Qaeda Organization and the Islamic State Organization: History, Doctrine, Modus Operandi, and U. S. Policy to Degrade and Defeat Terrorism Conducted in the Name of Sunni Islam. Carlisle: Strategic Studies Institute (SSI); U. S. Army War College Press.

22. Kapur, S. P. (2017). Jihad as Grand Strategy: Islamist Militancy, National Security, and the Pakistani State. New York: Oxford University Press.

23. LaFree, G., Dugan, L., Miller, E. (2015). Putting Terrorism in Context: Lessons from the Global Terrorism Database. Abingdon: Routledge.

24. LaFree, G., Freilich, J. D. (Eds.) (2017). The Handbook of the Criminology of Terrorism. Chichester: Wiley-Blackwell.

25. Laqueur, W. (1977). Terrorism. London: Weidenfeld and Nicolson.

26. Martin, M. (Ed.) (2011). The SAGE Encyclopedia of Terrorism. Second Edition. Thousand Oaks, Calif.: SAGE Reference.

27. Martin, S., Weinberg, L. (2017). The Role of Terrorism in Twenty-First-Century Warfare. Manchester: Manchester University Press.

28. McPhee, M. R. (2017). Maximum Harm: The Tsarnaev Brothers, the FBI, and the Road to the Marathon Bombing. Lebanon: ForeEdge.

29. Micuda, K. M. (2017). Combat Branding and the Islamic State: A Missing Link to Generating a Terrorist Recruit Profile. Doctoral Thesis, Fielding Graduate University, Santa Barbara, United States. Retrieved from https://pqdtopen.proquest.com/ pubnum/10258582.html.

30. Morris, T. (2017). Dark Ideas: How Neo-Nazi and Violent Jihadi Ideologues Shaped Modern Terrorism. Lanham: Lexington Books.

31. Muro, D. (Ed.) (2018). When Does Terrorism Work? Abingdon: Routledge.

32. Nesser, P. (2018). Islamist Terrorism in Europe. Revised \& updated ed. London: Hurst.

33. Schmid, A. P. (Ed.) (2011). The Routledge Handbook of Terrorism Research. New York: Routledge

34. Soufan, A. H. (2017). Anatomy of Terror: From the Death of bin Laden to the Rise of the Islamic State. New York: W. W. Norton \& Company.

35. Stenersen, A. (2017). Al-Qaida in Afghanistan. Cambridge: Cambridge University Press.

36. Vermaat, E. (2018). Terreur Aanslagen in Europa door Radicale Moslims. Soesterberg: Aspekt Publishing.

37. Wilkinson, P. (1974). Political terrorism. London: Macmillan; New York: Halsted Press.

38. Yeşiltaş, M., Kardaș, T. (Eds.) (2018). Non-State Armed Actors in the Middle East: Geopolitics, Ideology, and Strategy. Cham: Palgrave Macmillan / Springer Nature.

39. Antypenko, V. F. (2011). Mizhnarodna kryminolohiia: dosvid doslidzhennia teroryzmu: monohrafiia. Odesa: Feniks [in Ukranian].

40. Bielianska, V. V. (2014). Ideolohiia teroryzmu: pokhodzhennia i typolohichni vymiry: monohrafiia. Luhansk: Virtualna realnist [in Ukranian]. 
41. Gorlach, N. I., Trebin, M. P. (Eds.) (2006). Sovremennyj terrorizm: uchebnoe posobie dlja vysshej shkoly. Har'kov: Timchenko [in Russian].

42. Hryshchuk, V. K. (Ed.) (2011). Teroryzm: teoretyko-prykladni aspekty: navch. posib. Lviv: Lvivskyi derzhavnyi universytet vnutrishnikh sprav [in Ukranian].

43. Kantsir, V. S. (2011). Teroryzm u suchasnomu hlobalizatsiinomu prostori: filosofskopravovyi vymir: monohrafiia. Lviv: Krai [in Ukranian].

44. Krutov, V. V., Musiienko, I. I., Yemelianov, V. P. (Eds.) (2015). Teroryzm: vyznachennia i sutnist: monohrafiia. Kyiv: Natsionalna akademiia SBU [in Ukranian].

45. Leonov, B., Vasylyshyn, B. (2015). Teroryzm yak riznovyd sotsialnoho konfliktu. Naukovyi chasopys Natsionalnoi akademii prokuratury Ukrainy - Scientific journal of the National Academy of Public Prosecutor of Ukraine, 2, 66-71 [in Ukranian].

46. Trebin, M. (2004). Terrorizm kak destruktivnyiy modus byitiya. Psihologiya terroristov i seriynyih ubiyts: Hrestomatiya - Psychology of terrorists and serial killers: Chrestomathy (Pp. 230-252). Minsk: Harvest [in Russian].

47. Whittaker, D. J. (2004). Terrorists and Terrorism in the Contemporary World. London; New York: Routledge.

48. Baev, P. K. (2003). Examining the 'terrorism-war' dichotomy in the 'Russian-Chechnya' case. Contemporary Security Policy, 24(2), 29-46.

49. Sidorov, B. V., Kirshin, V. G. (2010). Terrorizm v ugolovnom prave: opredelenie, zakonodatel'naja reglamentacija i voprosy sovershenstvovanija zakonodatel'stva. Vestnik jekonomiki, prava i sociologii-Bulletin of Economics, Law and Sociology, 3, 104-111 [in Russian].

50. Trebin, M. P. (2017). Viina i teroryzm: symbiotychni vidnosyny. Visnyk Mariupolskoho derzhavnoho universytetu. Seria: istoriia, politolohiia - Bulletin of the Mariupol State University. Series: history, political science, 18, 365-373 [in Ukranian].

51. Merari, A. (1993). Terrorism as a Strategy of Insurgency Terrorism and Political Violence, 5(4), 213-251. Retrieved from https://www.researchgate.net/ publication/254267590_Terrorism_as_a_Strategy_of_Insurgency.

52. Cassese, A. (2003). International Criminal Law. Oxford; N. Y.: Oxford University Press

53. Jenkins, B. M. (1980). The Study of Terrorism: Definitional Problem. Santa Monica, Callif:: Rand Corp.

54. Falkenrath, R. A. (2001). Problems of Preparedness: U. S. Readiness for a Domestic Terrorist Attack. International Security, 25(4), 147-186.

55. Emel'janov, V. P. (1999). Terrorizm - kak javlenie i kak sostav prestuplenija. Har'kov: Pravo [in Russian].

56. Krajnev, A. (1997). Terrorizm - global'naja problema sovremennosti. Zarubezhnoe voennoe obozrenie - Foreign military review, 6, 5-8 [in Russian].

57. Marks, S., Clapham, A. (2005). International Human Rights Lexicon. Oxford; New York: Oxford University Press.

58. Schmid, A. P., Jongman, A. J., Stohl, M., et al. (1988). Political terrorism: a new guide to actors, authors, concepts, data bases, theories, and literature / foreword by 
I. L. Horowitz. Amsterdam; New York: North-Holland Pub. Co.; New Brunswick (USA): Transaction Books, distributors for the Western Hemisphere.

59. Skvorcov, L. V. Obshhestvo i nasilie. Retrieved from http://www.politic.donetsk.ua/ terror/terror013.shtml [in Russian].

60. Solov'ev, V. (1982). Duhovnye osnovy zhizni: (Spiritual Fundaments of Life), 18821884. Fototip. izd. Brjussel': Zhizn's Bogom [in Russian].

61. Vanhanen, T. (1979). Power and the Means of Power: a Study of 119 Asian, European, American, and African States, 1850-1975. Ann Arbor: University Microfilm International.

62. Aristotel' (1983). Politika. Works: in 4 volumes. Vol. 4 (Pp. 375-644). Moskva: Mysl' [in Russian].

63. Dahrendorf, R. (1988). The Modern Social Conflict: an Essay on the Politics of Liberty. London: Weidenfeld and Nicolson.

64. Antonjan, Ju.M. (2004). Kriminologija. Izbrannye lekcii. Moskva: Logos [in Russian]. 65. Midlarsky, M. I. (Ed.) (1986). Inequality and Contemporary Revolutions. Denver, Colo.: University of Denver.

66. Shihirev, P. (1992). Psihika i moral'v konflikte. Obshhestvennye nauki i sovremennost'Social Sciences and Modernity, 3, 27-37 [in Russian].

67. Dmitriev, A. V., Zalysin, I. Ju. (2000). Nasilie: socio-politicheskij analiz. Moskva: «Rossijskaja politicheskaja jenciklopedija» (ROSSPJeN) [in Russian].

68. Gusejnov, A. (1995). Moral'naja demagogija kak forma apologii nasilija. Voprosy filosofi - Philosophy issues, 5, 2-17 [in Russian].

69. Shnajder, G. J. (1994). Kriminologija / Per. s nem. Moskva: Progress - Univers [in Russian].

70. Gobbs, T. (1991). Leviafan, ili materija, forma i vlast' gosudarstva cerkovnogo i grazhdanskogo. Works in 2 volumes. Vol.2, Pp. 3-350. Moskva: Mysl' [in Russian].

Требин Михаил Петрович, доктор философских наук, профессор, заведующий кафедрой социологии и политологии, Национальный юридический университет имени Ярослава Мудрого, г. Харьков, Украина

\section{ФЕНОМЕН ТЕРРОРИЗМА: ПОНИМАНИЕ СУЩНОСТИ}

Раскрывается сущность феномена терроризма и обосновываются его основные признаки. К существенному признаку терроризма относится прежде всего насилие. Рассмотрены три типа теорий, объясняющих источники насилия: первый тип объединяет те концепции, которые выводят насилие из природы человека; второйвыводит применение насилия из экономических и сочиальных условий жизни общества; третий - связывает насилие с динамикой конфликта. При осуществлении террористических действий следует учитывать явный и латентный элементы насилия. Явный элемент насилия связан с осуществлением непосредственных террористических актов, латентный элемент насилия связан с тем, что террористи- 
ческий акт запускает механизм принуждения людей делать так, как этого требуют террористьл. Предлагается авторская дефиниция терроризма.

Ключевые слова: терроризм, террористический акт, насилие, война, дефиниция терроризма.

Требін Михайло Петрович, доктор філософських наук, професор, завідувач кафедри соціології та політології, Національний юридичний університет імені Ярослава Мудрого, м. Харків, Україна

\section{ФЕНОМЕН ТЕРОРИЗМУ: РОЗУМІННЯ СУТНОСТІ}

Постановка проблеми. Сучасний світ після подій 11 вересня 2001 р. живе з розуміниям того, що порлд з глобальними проблемами, які вже були усвідомлені людством наприкінці $X X \mathrm{~cm}$. (загроза ядерної війни, забруднення навколиинього середовица, зміна клімату, бідність і злидні в окремих регіонах планети), виникла ще одна загроза, яку теж можсна віднести до глобальних, - тероризм. Тероризм багатоликий і різноманітний, він трансформуеться разом з людством, він мімікрує під боротьбу з несправедливістю, нерівністю, пригнобленням, національно-визвольну боротьбу та іниі соціально-політичні прочеси, які можуть бути сприйняті амбівалентно. Тому проникнення в сутність тероризму, осмислення причин, способів і методів його боротьби, с особливо актуальним для України, яка вже п'ятий рік як стала об'сктом «гібридної» війни, у ході якої супротивник иироко використовує терористичні акти.

Аналіз останніх досліджсен та публікацій. Феномен тероризму став особливо активно досліджуватися вченими після трагедї̈ в Америці, хоча і раніме він перебував у полі їх зору. Але лиие за останні півтора десятиліття написано сотні книг і тисячі статей на цю тему, видані десятки енциклопедій, які досліджують дане явище. Серед вчених, які досліджують сутність, природу, форми і методи боротьби з тероризмом можна назвати таких дослідників за кордоном як М. Абрамс, А. Бреннан, С. Гоери, Б. Гоффман, Б. Дженкінс, Л. Дуган, М Крениоу, Д. Фрейліч, М Хамм, А. Хапим та ін. Велику увагу дослідженню тероризму приділяли й украйнські вчені, пакі як В. Антипенко, О. Бардін, А. Деменко, В. Смельянов, В. Крутов, В. Ліпкан, В. Мандрагеля, І. Мусієнко таін.

Формулювання цілей. Метою статті с спроба проникнути у сутність феномену тероризму і запропонувати дефініцію тероризму.

Виклад основного матеріалу. Осмислення тероризму як глобальної проблеми сучасності і з'ясування боротьби з ним с важливим гносеологічним завданням, ио вимагає негайного розв 'язання. Крім того, генезис даного явища свідчить про його значну трансформачію: зміноються форми здійснення терористичних актів, відбувасться зсув у полі иільового впливу терористів, змінюються методи їх діяльності, особливості організаційного будівництва та ін. Тероризм також має багато спільного з іниими формами соџіального протесту і насильства - агресісю, збройною боротьбою, військовими конфліктами різного ступеня інтенсивності, партизанськи- 
ми діями, диверсіями тощзо. У сучасній науковій літературі існує понад сто визначень тероризму. Хоча на рівні ООН на сьогодні не досягнуто жодної домовленості про визначення цього поняття. Американські досліднии тероризму підкреслюють, ио це явище легие описати, ніж дати йому чітке, однозначне тлумачення.

Однак саме по собі визначення тероризму дуже важливе. Визначити будь-яку дію як терористичну означає не просто стверджувати, иоо вона має певні характеристики, але і засудити ї̈. Спробусмо уточнити ряд моментів, пов 'язаних із дефініцісю тероризму. Кожне визначення повинне містити в собі істотні ознаки явища. На наи погляд, коли говориться про тероризм, то, по-перие, до таких ознак належить насильство. Склалися три типи теорій, иуо пояснюють джерела насильства. Периий тип поєднує ті концепції, щзо виводять насильство з природи людини. Другий тип теорій виводить застосування насильства з економічних і соціальних умов життя суспільства. Третій тип теорій зв 'язуе насильство з динамікою конфлікту.

Звичайне насильство має два основні трактування: примус і застосування фізичної сили. Системний аналіз допускає з 'ясування функиій насильства, які значною мірою зумовлені ступенем усвідомлення свойх дій суб' 'ктами насильства й остаточною метою насильства. Розрізняють так зване ірраціональне і раціональне насильство, а також інструментальне і символічне (чи «комунікативне») насильство.

3 погляду з'ясування особливостей насильства при здійсненні терористичних діянь варто акцентувати два моменти: явний і латентний елементи насильства. Явний елемент насильства пов'язаний із здійсненням безпосередніх терористичних актів, унаслідок яких гинуть люди, руйнуються будинки, вибухають літаки, потяги томуо. Латентний елемент насильства пов'язаний з тим, ио терористичний акт запускас механізм примусу людей робити так, як цього вимагають терористи, впливати на державні структури з метою реалізації на практиці тих вимог, ияо висувають терористи, створюе в суспільстві атмосферу страху та безвиході. Акиентування уваги на явному і латентному компонентах терористичноӥ діяльності дозволяє зафіксувати те, що явний компонент терористичних дій значною мірою показує інструментальну функцію терористичного акту як явица видового стосовно насильства; латентний компонент показуе генезу і динаміку такого явица, як наростання страху, безвиході в соиіумі, зростання ентропійних прочесів у ньому.

Аналіз суттевих ознак тероризму дозволяе сформулювати своє бачення тероризму. Під тероризмом розуміється сочіальне явище, засноване на використанні чи загрозі використання насильства у вигляді терористичного акту з метою нагнітання атмосфери страху і безвиході в суспільстві в ім'я досягнення мети суб 'сктів терористичної діяльності.

Висновки. Отже, тероризм - багатоликий, не зупинясться на місці, а постійно розвивається, як сочіальне явище він має дуже складну природу, його виникнення і розвиток залежсать від багатьох чинників, завдяки свойи деструктивності та руйнівності він є серйозною загрозою для суспільства й особистості.

Ключові слова: тероризм, терористичний акт, насильство, війна, дефініція тероризму.

\section{$\operatorname{son} 2$}

